УДК 811.161

https://doi.org/10.31548/philolog2021.03.021

\title{
МАРКЕРИ-ІДЕНТИФІКАТОРИ АНГЛОМОВНОГО МІЖНАРОДНО-ПРАВОВОГО ДИСКУРСУ
}

\author{
М. І. ЛИчУК, доктор філологічних наук, доцент, \\ Національний університет біоресурсів і природокористування України \\ E-mail: mariya.lychuk@gmail.com \\ https://orcid.org/0000-0002-8046-7414
}

Анотація. Стаття присвячена систематизації мовних маркерів різних семантичних різновидів у структурі міжнародно-правового дискурсу. Дотичною є проблема ролі цих маркерів у процесі правової міжкультурної комунікації. Міжнародно-правова картина світу $\epsilon$ системою деонтичних, онтологічних та аксіологічних концептів, що охоплюють різнобічні знання й уявлення про належну поведінку держави, а це так само є результатом онтологізації нормативного змісту міжнародних документів і параметрів середовища, пов'язаного з дискурсивним простором міжнародного права.

У статті визначено особливості юридичного, зокрема міжнародно-правового, дискурсу та його ознаками. Мова права характеризується такими важливими ознаамки: офріційність; раціональна стислість; логічність; однозначність; точність; нейтральність; стандартизованість; нормативність

Схарактеризовано групи мовних маркерів у структурі англомовних міжнародно-правових договорів та їхні значеннєві особливості. Мовні маркери англомовного типу ідентифікують англомовний юридичний дискурс та автора як глибокого знавця англійської мови. Вони сфрормували такі групи: синонімічні пари; багатокомпонентні словосполучення; лексеми з оновленою, юридичною, семантикою; скорочення та абревіатури; іншомовні лексеми; юридичні штампи. Спостереження виявили найчастотніші групи у текстах міжнародно-правових договорів: багатокомпонентні словосполучення, абревіатури й іншомовна лексика. Менш уживаними є групи архаїзмів, модальних дієслів shall (зобов'язуватися) та тау (у змозі).

Перспективи досліджень пов'язані з подальшим вивченням ффункціонально-прагматичних характеристик текстів англомовних міжнародних юридичних договорів.

Ключові слова: англомовний юридичний дискурс, маркер, синонімічна пара, іншомовна лексема, юридичний штамп.

За останнє сторіччя стан лінгвістичної науки характеризується бурхливим розвитком і зміною аспектів, що оприявнюються у різноманітних наукових дослідженнях. На межі XX і XXIст. центральні позиції в мовознавстві займають комунікативна (в повному обсязі її напрямів антропонімічного, когнітивного, етно-, психо-, соціолінгвістичного, фуннкціонально-семантичного та лінгвопрагматичного) й когнітивна мегапарадигми, які визначають загальне спрямування лінгвістичного знання. Як наслідок нової парадигми в лінгвістиці - система наукових уявлень про об'єкти дослідження еволюціонувала, що уможливило розширити соеру вивчення специфіки мовних фрактів, зокрема у структурі англомовного юридичного тексту.

Актуальність дослідження зумовлена потребою систематизації значеннєвої специфіки мовних маркерів у структурі міжнародно-правового дискурсу та визначення їхньої ролі для правової міжкультурної комунікації.

Аналіз останніх досліджень та публікацій. У лінгвістичних наукових розвідках останніх років дослідники розглядають дискурс як багатовимірне явище $[7 ; 9]$ із урахуванням когнітивних, етнопсихологічних, культурних, соціальних та інших чинників [10, с. $23 ; 28 ; 11$, c. 208].

Поняття дискурс трактують як складне явище, що містить такі складники: учасники комунікації, ситуації спілкування і текст. Дискурс - це замкнена цілісна комунікативна ситуація (подія), що об'єднує комунікантів і текст як знакового посередника, яка зумовлена різними чинниками (соціальними, культурними, етнічними), що опосередковують спілкування й розуміння $[11$, с. 223$]$.

T. Ван Дейк трактує дискурс як комунікативну подію, спосіб актуалізації тексту в певних ментальних і прагматичних умовах [10, с. 48]. Дослідники зазначають, що дискурс - це «мова в мові», особлива соціально спрямована форма буття мови. Дискурс не можна ототожнювати зі стилем, він $€$ особливою підмовою у цілісній мовній системі [6].

Міжнародно-правовий дискурс визна-чають як синергетичну систему, «складники якої взаємно детерміновані й залежні від параметрів зовнішнього середовища, зокрема, соціуму, культури, політики, права, інтеріоризованого буття етносу й цивілізації» [8, с. 28]. Міжнародно- 
правова картина світу є системою деонтичних, онтологічних та аксіологічних концептів, що узагальнюють універсально-узуальні знання й уявлення про належну поведінку держави, $€$ результатом онтологізації нормативного змісту міжнародних документів і параметрів середовища, пов'язаного 3 дискурсивним простором міжнародного права [8, с. 29; 9, с. 44].

Мета дослідження - визначити семантичні групи мовних маркерів у структурі англомовних міжнародно-правових договорів, схарактеризувати їхні значеннєві особливості та роль у процесі міжкультурної правової комунікації.

Методи дослідження: У процесі дослідження застосовано такі методи: аналіз, синтез, узагальнення, систематизація, описовий та трансформаційний метод дослідження.

Результати дослідження. Юридичний дискурс поряд з політичним, економічним та іншими є різновидом інституційного дискурсу, що має чітку мету, визначених учасників i встановлений шаблон розгортання мовленнєвої ситуації. Юридичний дискурс тлумачать як «результат» когнітивної діяльності людини у галузі права, як вербальний результат класифікації світу, що вимагає упорядкування правової інформації та іï адекватної інтерпретації [9, с. 122]; «смислоутворювальна діяльність, що регламентується певними історичними і соціальними кодами (традиціями), спрямована на формулювання норм, правове закріплення (легітимізацію), регулювання і контролювання суспільних відносин» [6, с. 3]; «текст права в динаміці, в процесі тлумачення і роз'яснення» [2, c. 165].

Оскільки право - це «сукупність встановлюваних керівництвом країни норм і правил, що регулюють відносини людей у суспільстві, а також наука, що вивчає ці норми» [7, с. 133], то й юридичне функціонування мови особливе середовище. У цьому середовищі сорормулювалися певні внутрішні закономірності, що склалися у правотворчих i правозастосувальних процесах, закріплені у спеціальних законодавчих актах чи прийняті в юридичній практиці. Мові права властиві такі ознаки: офіційність; раціональна стислість; системність; логічність; об'єктивність; вмотивованість; однозначність; достовірність; зобов'язально-інформативний характер; зрозумілість, точність і визначеність; нейтральність; стандартизованість; сталість; нормативність [8, с. 32].

Мовна система юридичного дискурсу відбиває певний ідеал суспільного устрою і суспільних відносин, відповідно до якого реалізуються дискурсивні стратегії конструювання та реконструювання соціальної реальності. Юридична дискурсивна практика неможлива без текстової основи, яка $€$ одночасно і практичним орієнтиром, і догматичним виправданням юридичних дій та знаковою формою права [1, с. 54].

Текст юридичних документів - головний складник юридичного дискурсу. Він виконує не тільки інформаційну функцію, а й розкриває соціально-прагматичну позицію автора тексту. Учасниками юридичного дискурсу є, 3 одного боку, автор (професіонал-юрист), а 3 іншого боку, - реципієнт. Перший створює інформаційне повідомлення, висловлюючи сутність юриспруденції, другий сприймає та інтерпретує повідомлення. Юридичний текст має риси подібності як з науковим текстом, так і 3 текстом інструкції, оскільки виконує і пізнавальні, і розпорядчі фрункції. Таке комунікативне завдання мають закони, включаючи Основний закон (Конституцію), а також всі підзаконні акти. Джерелом юридичних текстів $є$ профресіонали-юристи, що створюють ïх 3 урахуванням особливостей устрою суспільства. Комплекс засобів, характерний для юридичного тексту, забезпечує повноцінну передачу інформації реципієнту, тобто будьякій людині, однак особі для розуміння (тлумачення) будь-якого закону потрібна допомога фахівця.

Юридичний текст $є$ особливою юридичною термінологічною системою. Когнітивно-дериваційна і соціальна сутність юридичної лексики виражається в ії здатності формувати поняттєво-смислові блоки, компоненти яких можуть класифікуватися за певними моделями [3, с. 39].

Ми визначили певні мовні маркери, що ідентифікують англомовний юридичний дискурс та автора як глибокого знавця рідної англійської мови.

1. Особливістю англомовних юридичних текстів є використання синонімічних пар: alter and change, free and clear, true and correct [8, c. 46]. Ha думку дослідників, використання синонімічних пар має давню історію. У різні історичні епохи англійські юристи використовували слова двох мов, що паралельно фрункціонували в країні: англійської / латинської, пізніше - англійської / французької .Так, наприклад, синонімічна пара free and clear поєднує в собі староанглійське freo i старофранцузьке cler. Юристи почали використовувати слова з кожної мови і з'єднувати в пари, щоб висловити єдине значення. Це подвоєння використовувалося для надання більшої ясності, а також для акцентування значення. Поступово подвоєння стало модою, а потім традицією юридичної мови. Незнання цієї особливості ставить сучасного читача, який вивчає англійську мову в глухий кут.

2. Особливістю юридичного тексту $\epsilon$ 


\section{використання}

словосполучень.

\begin{abstract}
Такі
\end{abstract}
багатокомпонентних словосполучення

складаються з трьох, чотирьох слів замість одного або двох, наприклад: notwithstanding of the fact that; at that point of time; with reference to; in accordance with [4, с. 170]. Ці словосполучення невиправдано подовжують речення і роблять зміст висловлювання не зовсім зрозумілим і ясним. Ці речення можна перефразувати, уникаючи складених словосполучень, кожне 3 яких може бути замінене більш простою формою. Напр.: Notwithstanding of the fact that - although, at that point of time - then, with reference to - about, in accordance with - by or under. Так, наприклад, речення The parties were in complete agreement with respect to the amount of rent due and also as regards the due date, можна озвучити по-іншому The parties were in complete agreement about the amount of rent due and about the due date [42:198].

Англійські речення юридичного контексту відрізняються тим, що часто вони написані у формі єдиного речення (до 200 слів), яке містить кілька блоків основної інформації та другорядні речення, що несуть додаткову інформацію. Коли юрист пише, він намагається в одному складному реченні донести до читача всі основні ідеї, що підтримують доводи, деталі, винятки і висновки. Тому часто такий вислів втрачає ясність, його важко зрозуміти, наприклад: In a trial by jury, the court may, when the convenience of witnesses or the ends of justice would be promoted thereby, on motion of the party, after notice and hearing, make an order, no later than the close of the pretrial conference in cases in which such pretrial conference is to be held, or in other cases, no later than 10 days before the trial date, that the trial of the issue of liability shall precede the trial of any other issue in the case. Це речення, що складається з 86 слів, містить 5 блоків інформації, і його важко зрозуміти після першого прочитання, тому що порушено логічний порядок передачі інформації [7, с. 134].

3. У тексті юридичної документації часто зустрічаються випадки використання слів, які в юридичному документі не використовуються у своєму «повсякденному» значенні, а набувають нового значення "юридичного» характеру: consideration - 'зустрічне задоволення' [13, с. 74; 5, c. 149]; order for relief - 'рішення про застосування правових заходів' [13, с. 187]; subsidiary promise 'додаткове зобов'язання' [13, с. 230].

4. Використання архаїзмів - ще одна характерна особливість юридичної англійської мови. Застарілі слова датовані 16 століттям, $€$ словами й виразами, якими широко послуговувалися в минулому, однак на сьогодні характерні тільки для юридичної мови. До архаїчних слів належать слова, що складаються із прислівників місця, до яких додається суфікс у вигляді прийменника, напр.: hereto, hereof, hereupon, herein, hereafter, hereinbefore, thereof, whereof та ін. [4, с. $67 ; 5$, c. 148-149].

5. у юридичному тексті широко використовують скорочення та абревіатури, напр.: латинські слова або вирази ad hoc, exempli gratia (e.g.), et cetera (etc.), per se, sic, versus (vs.); латинські терміни: de facto, ipso facto, inter alia, per annum, pro forma, pro rata, quorum, sui juries, ultra vires, videlicet [10, с. 73].

6. У юридичних текстах, як і в будь-яких інших, зустрічається іншомовна лексика. Багато термінів в юридичній англійській мові було запозичено з французької, напр.: voir dire 'попередня перевірка компетентності та допуску присяжного' [5]; estoppel 'позбавлення сторони посилатись на будь-які факти' [5, с. 152]. Латинізми, що вживаються в англійській мові, лексика римського права, напр.: mutatis mutandis 'з відповідними змінами' [12, с. 431]; inter alia 'окрім іншого'; prima facie 'достатньо, якщо інше не доведено' [12, с. 433].

7. Особливістю юридичних документів $€$ вживання модальних дієслів shall (зобов“язуватися) та тау (у змозі).

8. Іншою важливою ознакою юридичних текстів є залежність значення слова від його граматичної форми. Так, одне й те ж саме слово може в однині і множині мати різні значення, наприклад: interest - 'відсоток', а слово interests - 'частка капіталу компанії'; law - 'закон', а вживання цього ж слова в множині з означеним артиклем the laws означає 'законодавство' [4, с. 166].

Існування «хибних друзів перекладача» це особливість, яка також властива юридичній англійській мові. «Хибні друзі перекладача» це лексичні одиниці, близькі за написанням та звучанням в мові оригіналу та мові перекладу, але відрізняються своїм значенням, наприклад: instrument - не 'інструмент', а 'документ, який $є$ правовим актом', examination - не 'екзамен', а 'допит, розслідування справи'.

«Хибні друзі перекладача» поділяють на три види [3, с. 89; 7, с. 132]:

1. Слова, що мають зовнішню подібність зі словами мови перекладу, однак їхнє значення не збігається, напр.: data 'дані' [12], principal 'основна сума кредиту' [12].

2. Багатозначні слова, в яких частина значень збігається зі значенням мови перекладу, а частина - ні, напр.: authority 'влада, компетентний орган', а не лише 'авторитет'[12].

3. Слова мови оригіналу, які близькі за написанням та звучанням і які мають відповідно різні значення, напр.: personal 'особистий' - personnel - 'персонал' [12] [7, c. 133].

9. Притаманною рисою юридичних 
документів є юридичний штамп. Це певний шаблон, стереотип, що існує в мові, зазвичай письмовій, протягом довгого періоду, який визнали та широко застосовують спеціалісти у copepi права, напр.: effective date 'дата набуття чинності' [12]; as provided hereby 'в порядку, передбаченому цим документом' [12]; the law provides for 'законом передбачається' [12]; in witness whereof 'на підтвердження чого' [12].

Специфріка термінів визначає важливість їхнього точного застосування, що визначає системність функціонування такого явища, як право. Саме системність порушується під час неправильного, неадекватного перекладу термінів, без урахування національно-правової специфіки та первинного функціонування. Уникнути таких помилок може тільки спеціаліст, який володіє достатніми знаннями у сорері лінгвістики та теорії перекладу.

Висновки і перспективи дослідження. Аналіз текстів англомовних міжнародно-

\section{Список використаних джерел}

1. Авакова О. В. Формирование и функционирование английской юридической терминологии в процессе становления государства и права в Англии: диссертация кандидата фрилологических наук : 10.02.04. Москва, 2006. 208 с.

2. Артикуца Н. В. Термінологічноправовий фонд української мови: проблеми методології дослідження. Система і структура східнослов'янських мов. Київ : Вища шк., 1999. C. 164-187.

3. Калюжна В.В. Стиль англоязычных документов международных организаций. Київ : Наук. думка, 1982. 122 с.

4. Кияк Т.Р. Основи термінотворення: Семантичні та соціолінгвістичні аспекти. Київ : Видавничий дім «КМ Academia», 2000. 218 с.

5. Клочко М.І. Юридична термінологія: поняття, особливості. Державне будівництво та місцеве самоврядування. Випуск 18. 2009. C. $148-154$.

6. Кожемякин Е. А. Юридический дискурс как культурный феномен : структура и смыслообразование. URL: http:// konference.siberia-expert.com

7. Костенко Л. Мовні аспекти юриспруденції. Юридичний журнал. 2006. № 2. С. 132-134.

8. Прадід Ю.Ф. Вступ до юридичної лінгвістики: [навч. посіб.] Сімферополь : Доля, 2002. 104 c.

9. Словничок юридичних термінів / Укладач В. П. Марчук. Київ : Міжрегіональна академія управління персоналом, 2003. https://moskalik.at.ua/pravo/PR4_01.pdf

10.Brown G. Discourse Analysis.Cambridg : Cambridge University Press, 2008. 288 p. правових договорів уможливив виявити певні мовні маркери - лексеми і словосполучення та їхні значеннєві характеристики. Визначено дев'ять найважливіших особливостей таких мовних маркерів. 3 позиції частотності уживання у структурі англомовного юридичного дискурсу акцентовано на таких особливостях мовних маркерів як використання синонімічних пар, лексем у новому юридичному значенні, іншомовної лексики та юридичних штампів. Мовні маркери, ґрунтовані на основі національного і міжнародного права, випливаючи із їхньої сутності, роблять зрозумілою правову міжкультурну комунікацію між правовими суб'єктами різних держав.

Перспективи подальших досліджень убачаємо у вивченні функціональнопрагматичних характеристик текстів англомовних міжнародних юридичних договорів.

11.Fairclough N. Discourse and text: linguistic and intertextual analysis within discourse analysis. Discourse and Society. 2003. № 3 . P. 206-211.

12. Mellinkoff D. The Language of the Law. Boston : Little, Brown, 1963. 526 p.

13.Tiersma P. Legal language. Chicago : University of Chicago Press,1999. 328 p.

\section{References}

1. Avakova, O. V. (2006). Formirovanie $i$ funktsionirovanie angliyskoy yuridicheskoy terminologii v protsesse stanovleniya gosudarstva $i$ prava $v$ Anglii [Formation and functioning of English legal terminology in the process of the formation of state and law in England: dissertation of the candidate of philological sciences]: dissertatsiya kandidata filologicheskih nauk : 10.02.04. Moscow.

2. Artykutsa, N. V. (1999). Terminolohichnopravovyi fond ukrainskoi movy: problemy metodolohii doslidzhennia [Terminological and legal fund of the Ukrainian language: problems of research methodology]. Systema $i$ struktura skhidnoslovianskykh mov. Kyiv : Vyshha shkola.

3. Kalyuzhna, V. V. (1982). Stil angloyazyichnyih dokumentov mezhdunarodnyih organizatsiy. Kyiv : Naukova dumka.

4. Kyiak, T.R. (2000). Osnovy terminotvorennia: Semantychni ta sotsiolinhvistychni aspekty. Kyiv : Vydavnychyi dim «KM Academia».

5. Klochko, M. I. (2009, 18). Yurydychna terminolohiia: poniattia, osoblyvosti. Derzhavne budivnytstvo ta mistseve samovriaduvannia. 148154.

6. Kozhemyakin, E. A. (2002). Yuridicheskiy diskurs kak kulturnyiy fenomen : struktura $i$ 
smyisloobrazovanie. Retrieved from http:// konference.siberia-expert.com.

7. Kostenko, L. (2006). Movni aspekty yurysprudentsii. Yurydychnyi zhurnal, 2. 132-134.

8. Pradid, Yu. F. (2002). Vstup do yurydychnoi linhvistyky. Simferopol : Dolia.

9. Slovnychok yurydychnykh terminiv (2003). Ukladach V. P. Marchuk. Kyiv : Mizhrehionalna akademiia upravlinnia personalom. Retrieved from https://moskalik.at.ua/pravo/PR4_01.pdf.
10.Brown, G. (2008). Discourse Analysis. Cambridg : Cambridge University Press.

11.Fairclough, N. (2003). Discourse and text: linguistic and intertextual analysis within discourse analysis. Discourse and Society, 3, 206-211.

12.Mellinkoff, D. (1963). The Language of the Law. Boston : Little, Brown.

13.Tiersma, P. (1999). Legal language. Chicago : University of Chicago Press.

\title{
MARKERS-IDENTIFIERS OF ENGLISH LANGUAGE INTERNATIONAL LEGAL DISCOURSE M. I. Lychuk
}

\begin{abstract}
The article is devoted to the problem systematization semantic specificity of language markers in the structure of international legal discourse. In linguistic scientific research in recent years, researchers consider discourse as a multidimensional phenomenon taking into account cognitive, ethnopsychological, cultural, social and other factors. Discourse is a communicative event, a way of actualizing the text in certain mental and pragmatic conditions. International legal discourse is defined as a synergetic system, the components of which are mutually determined and dependent on the parameters of the external environment, in particular, society, culture, law, etc. The purpose of the study is to identify groups of language markers in the structure of English-language international legal agreements, to characterize their semantic features and role in the process of intercultural legal communication. Legal discourse is interpreted as the result of human cognitive activity in the field of law, as a verbal result of the classification of the world, which requires the organization of legal information and its adequate interpretation. The text of legal documents is the main component of legal discourse. It performs not only an informational function, but also reveals the socio-pragmatic position of the author of the text. Participants in the legal discourse are, on the one hand, the author (professional lawyer), and on the other hand - the recipient. English-language legal discourse is identified by certain language markers. 1. Using synonymous pairs: alter and change, free and clear, true and correct. For example, the synonymous pair free and clear combines Old English freo and Old French cler. Lawyers began using words from each language and pairing them to express a single meaning. 2. A feature of the legal text is the use of multicomponent phrases. Such phrases consist of three, four words instead of one or two, for example: notwithstanding of the fact that; at that point of time; with reference to; in accordance with. Such examples can be paraphrased, avoiding compound phrases, each of which can be replaced by a simpler form. 3. In the text of legal documentation there are often cases of using words that acquire a new meaning of «legal» nature: order for relief - 'рішення про застосування правових заходів'. 4. Use of foreign vocabulary. Many borrowings from French and Latin. 5. Used by legal stamps.

Analysis of the texts of English-language international legal agreements made it possible to identify certain language markers - tokens and phrases and their semantic characteristics. From the standpoint of frequency of use in the structure of English-language legal discourse, emphasis is placed on such features of language markers as the use of synonymous pairs, tokens in the new legal meaning, foreign language vocabulary and legal stamps. Language markers based on national and international law, following from their essence, make clear legal intercultural communication between legal entities of different states. We see prospects for further research in the study of functional and pragmatic characteristics of the texts of Englishlanguage international legal agreements.
\end{abstract}

Keywords: English legal discourse, marker, synonymous pair, foreign word, legal stamp. 